\title{
CSR IN CLUSTERS IN THE CONTEXT OF POSITIVE ORGANIZATIONAL SCHOLARSHIP
}

\author{
Anna HORZELA \\ Silesian University of Technology, Zabrze, Poland; anna.horzela@polsl.pl; ORCID: 0000-0003-2345-9861
}

Purpose: The objective of this article is to present a new direction in management (POS) from social responsibility perspective, using clusters as an example.

Design/methodology/approach: The article is based on an in-depth literature analysis, taking into account the definition of Positive Organizational Scholarship and corporate social responsibility. The subject of the analysis will be clusters as network organizations.

Findings: The concepts presented in the article are the Positive Organizational Scholarship, the subject of which is the cause and effect chain. Its initial link is the specific configuration of organization resources and the final link are the results that are a proof of the organization development. The second discussed concept is corporate social responsibility that is the foundation for Positive Organizational Scholarship. The system of Corporate social responsibility management, in particular the ISO 26000 standard, is a key factor for the development of the abovementioned concept.

Research and practical limitation/implications: The research is of theoretical nature. It is an introduction to quantitative and qualitative research in selected clusters, taking into account POS and CSR provisions.

Originality/value: The article is an original approach to the activity of clusters in the context of corporate social responsibility and Positive Organizational Scholarship.

Keywords: CSR, clusters, cooperation networks, social responsibility, Positive Organizational Scholarship.

Category of the paper: Viewpoint.

\section{Introduction}

Development is a natural objective of every organization. Numerous sciences, among others the management sciences, look for answers to the question: how to ensure development for the studied enterprises? The subjects of their research are organizations, especially enterprises that are the main value creators influencing the social and economic level of a country. Management sciences distinguish many concepts and theories of company development. They differ in terms 
of interrelations and the complexity level. Some of them complement one another, other compete with each other, The environment of every organization makes it difficult to create one universal concept. However, we should not abstain from searching for such a concept, as selected mechanisms and areas can be combined with other concepts concerning different issues to create added knowledge. The changes taking place in the environment concern, among others, objectives, strategies, organizational structure, processes, organizational culture, attitudes and behavior of employees, thus influencing the development of an enterprise.

In the management sciences we can observe a new trend, the basics of which is the assumption that the key for organization development is the employees' behavior (GlińskaNewes, 2011). New approach to organization management problems focuses on the study of positive results, processes, organization features and innovative behaviors of the employees. It focuses on the search of such dynamics, that lead to the development of employees and of the whole organization, cultivate the outstanding results, as well as focus on the positive processes and phenomena. This new perspective of approaching enterprise development conditions is defined as Positive Organizational Scholarship (POS) (Czop, 2012).

The article is of theoretical nature. It is based on the results of literature studies. The objective of this article is to present a new direction in management (POS) from social responsibility perspective. The subjects of the analysis are clusters as specific forms of cooperation. It was assumed that in a network organization, such as a cluster, there is a need and a possibility to carry out a business that is socially responsible. The analysis was based on standards developed by Polish Agency for Enterprise Development.

\section{Positive Organizational Scholarship}

Until recently, in the organizational research, the positive phenomena were ignored (Wright, Cropanzano, 2004). However, the interest in the organizational life increased (Cameron et al., 2011). Since the publication of a groundbreaking book titled Positive Organizational Scholarship - POS (Cameron et al., 2003), the area of organizational sciences was enriched with new approaches and ideas. The research carried out by prominent scientists in the scope of POS indicate, that it is a direction strongly based on positive approaches and perspectives that ensure new paths for research on organizational life. What distinguishes the POS research is the fact that the researchers take into account negative approaches that usually shape the organizational research. They support the search of positive values, as well as of the organizational dynamics and systems. As stated by Cameron, it is important to state that "the study of positive phenomena is not completely one-sided, as positive and negative aspects are often linked by way of causes" (Cameron, 2007). 
There are several reasons to study positive phenomena. According to Cameron (2003) this is demonstrated by the fact that both the humanity and the organization can develop and thrive even if they face difficult, threating, unambiguous or turbulent conditions. This fact indubitably is a proof of strength sourced from positive phenomena, when one feels motivated to mitigate and overcome the more influential negative events and factors. Moreover, the organizations are now aware of the benefits associated with "establishing a positive work context". As a result, it is believed that "positive work environment can bring about many desired work results, such as more beneficial approach to work and increase of work efficiency" (Valentine et al., 2011). In turn, Fredrickson (2009) claims that positivity has more depth and covers a range of positive emotions, such as recognition, love, happiness, hope and gratitude. He suggests that positivity changes the contents, scope and boundaries of our minds. Moreover, it can widen the scope of possibilities we anticipate in our lives.

The issue of positivity is based on a concept that people cultivate the internal need of selffulfillment to express their full potential (Fineman, 2006). According to Fineman "Positive experiences, learning and changes are associated with negative phenomena and events (...)" (Fineman, 2006). Fredrickson adds that negativity and neutrality limit our experiences and knowledge about the world, while positivity does the exact opposite" (Fredrickson, 2009). In turn, Ghoshal (2005) warns that positive approach will not make any progress until the researches change their efforts towards participation in new research streams and take a risk. Positivity is an attractive concept, especially for those who are disappointed with materialism of the advanced economies and organizations, characterized by lack of empathy or sensitivity towards their members. This is also the source of a significant need of change resulting from the positive potential that can be used in the future (Fineman, 2006).

Polish researchers also carried out research on Positive Organizational Scholarship. As stated by Czekaj and Ziębicki (2013): "the main assumption of this direction is to focus on management, on developing positive aspects of organization that foster development and success instead of focusing on preventing malfunctions and organizational dysfunctions". In turn, Czerw and Babiak add that POS is about: "searching in organizations such dynamics, that lead to employees' development, support their potential, vitality and creativity, cultivating above-average results - both of the organization and its employees. It, therefore, emphasizes the role of, for example, such features of employees as creativity, motivation for success, optimism, emotional intelligence, as well as cognitive and emotional states that are beneficial for the organization: engagement in work, work satisfaction or sense of self-fulfillment. POS also indicates the specific importance of properly shaped organizational culture, based on implementation of values associated with employee development and development of modern positive motivation systems" (Czerw, Babiak, 2010).

POS assumptions can be analyzed in the context of the three elements of its name. Positive - it is the willingness to understand positive states, such as resilience, persistence, fulfillment and dynamics, as well as results associated with these states - gratitude or positive human 
relations. Organizational - POS focuses on positive processes and states occurring in organizations. It is not only about the study of positive phenomena present in organizations, but also about exploration of the organizational context that could be labeled as positive. The considerations are carried out at the organizational level and not at the level of an entity a human - as it is the case of positive psychology. Scholarship - this element emphasizes the scholarly approach to the issues presented above. However, it is not only about a clear answer to the question how to establish a positive organization that fully uses the human potential and where the employees feel fulfilled, satisfied and can be themselves at work. It is more about understanding causes and effects of positive phenomena and their dynamics, to use them consciously in organization management and human capital (Kalinowska-Andrian, 2006).

Moreover, research works in related disciplines, such as positive psychology, recognition, pro-social attitude, civic behaviors, community, psychology, corporate social responsibility, ethics, creativity and in all other disciplines are examples of social sciences research streams that overlap with positive phenomena. The mentioned corporate social responsibility focuses on the obligation of an organization, especially corporation, on solving social problems (Whetten, Rands and Godfrey, 2001). The US government asked the corporations to engage in the promotion of social welfare. In the recent years, many non-governmental organizations were established for the purpose of solving social problems. The academic disciplines mentioned before study, among others, human rights, strategy and organizational behavior, focusing on engagement in responsible social activities and relations between the social results of an enterprise and its financial results. The literature overview of Margolis and Walsh (2002) provides that $53 \%$ of the studied enterprises indicated a positive relation between the social and financial results, where the financial results were the dependent variable. In turn, $68 \%$ of respondents, whose financial result was treated as independent variable, indicate positive correlation between the financial results of an enterprise. The cited research indicate the multitude of positive phenomena in organizations. However, a majority focuses on overcoming barriers and problems, instead of focusing on thriving, positive dynamics and growing human development. POS, as a new management trend, tries to use the traditional research links, as well as represents the extension of the currently known generative and life-giving phenomena in organizations. The researchers urge to apply more positive attitude to leadership (Wang and Thompson, 2006), as well as to integrate in the scope of business ethics and POS through approach establishing strengths, to understand the business ethics and corporate responsibility (Giacalone, Jurkiewicz and Dunn, 2005) or to focus on how ethics, as a field, provides a valuable philosophy of POS basics (Sonenshein, 2005). 


\section{Corporate Social Responsibility in clusters}

As the modern economic, social and ecological problems grow, the concept of social responsibility of all social and economic entities becomes more and more widespread. It applies not only to entrepreneurs, but also to entities of other economy sectors and to citizens. Using the CSR rules as a guidance in business should be a common practice, both for organizations and for entities. The ultimate goal should be the improvement of the quality of life of the current and future generations.

In literature, there are many varied definitions of CSR. Within the same term, there are several depending and complementing approaches. One can name such approaches as (Dahlsrud, 2008):

- environmental one, that is about undertaking business activity that will not harm the environment and that improves its quality,

- charitable approach, entailing undertaking social activities that do not result from formal obligations,

- social, indicating relations between organizations and the community,

- economic, taking into account CSR rules in business activity,

- ownership, taking into account the interests of all stakeholders.

"It is assumed that the organizations using CSR rules must remember about fair treatment of employees, ethic activity, taking into account various needs, interests, respecting basic social rights, maintaining good relations with the environment and about the fact that the natural environment must serve future generations" (Bugdol, 2010). The international ISO 26000 standard Guidance on Social Responsibility defines corporate social responsibility as: "an organization's responsibility for the impacts of its decisions and activities on society and the environment, through transparent, ethical behavior, which contributes to sustainable development, including the health and well-being of society, takes into account the expectations of stakeholders (persons or groups that are interested in the decisions or activities of the organization), complies with laws in force, is compatible with international standards of behavior and is integrated throughout the organization and implemented in its relations" (ISO 26000, 2011).

In practice, CSR is about emphasizing the necessity to take into account also non-economic issues in the business model and to assign them a significant meaning. It is an emphasis of the fact that one must constantly aim to achieve economic values, at the same time minimizing the social and environmental costs. Such an approach undermines the traditional presumptions, based on profit maximization, respecting the law and potential charity, being about sharing one's wealth with the community. Within this meaning, CSR is about rejecting the model of strategy directed towards the interests of the owners only - Shareholders Strategy (RosińskaBukowska, 2012). The modern management strategy is about the art of reconciling the 
expectations of various shareholders' groups, therefore, it is an implementation of Stakeholders Strategy. J. Jonker, A. Rudnicka, J. Reichel combine the views of M. Friedman and R.E. Freeman discussing the "Friedman vs. Freeman" approach. M. Friedman emphasizes that the social objective of every business is to multiply the profit (Jonker, Rudnicka, Reichel, 2011; Friedman, 1970). In turn, the theory of Ansoff and Steward, developed by Freeman, assumed that an enterprise is an element of community, therefore, it should take care of it and try to meet the needs of particular stakeholders' groups (Ejdys, Gulc, 2015), including investors, governments, employees, cooperants, trade associations to fulfill the concept of strategic management (Freeman). In terms of stakeholder types, the social responsibility can be divided into internal and external stakeholders. Their division is presented in Fig. 1 (Adamczyk, 2009).

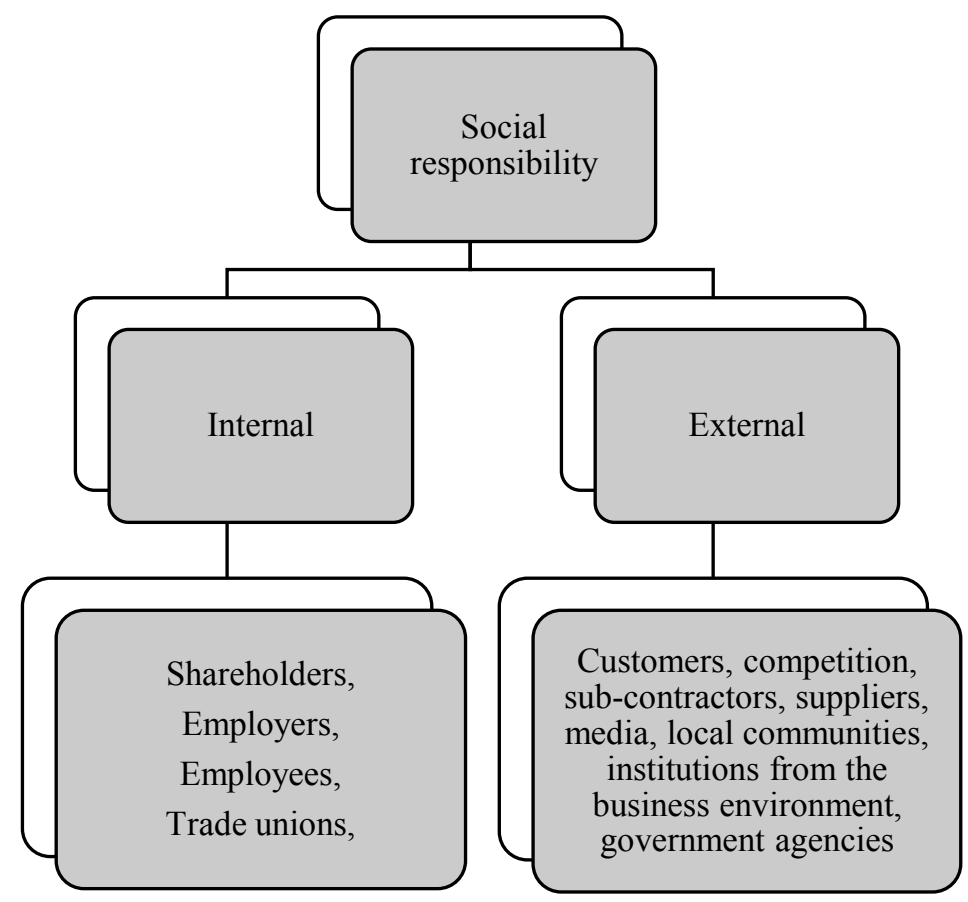

Figure 1. CSR categories according to stakeholders. Adapted from "Społeczna odpowiedzialność przedsiębiorstw" by J. Adamczyk, 2009, PWE, Warszawa.

According to Żemigała, CSR is about "specific sensitivity to the matters of the external environment (social, ecologic sensitivity), the ability to maintain balance between the interests of the customers, employees and shareholders and rendering certain services for the local community (Żemigała, 2007). Corporate social responsibility is a manner of carrying out business, not only by economic entities, but also by other organizations from various communities and sectors: medicine, culture, public administration, non-governmental organizations and scientific research entities.

Social responsibility fits into the management strategy by being an important element of building the image and identity of an organization and its organizational culture. This concept is being introduced and implemented at the level of autonomous entities. In accordance with the above, it can be assumed that in a network organization, such as a cluster, there is a need and a possibility to carry out business that is socially responsible. 
The roots of clusters concept must be looked for in the concept of industrial districts formulated by A. Marshall at the turn of the 20th century. The clusters were defined and popularized by M. Porter, who defined them as agglomerations of interlinked companies, specialist suppliers, entities rendering services, companies operating in related sectors and institutions associated with them (universities, standardization entities and industry associations), in particular fields competing, but also cooperating with one another (Porter, 2001). The traditional cluster, as defined by Porter, is based on geographic concentration of entities, sectoral concentration and the competition and cooperation taking place at the same time. Dynamic development of ICT measures, elimination of multiple issues of technical and legal nature associated with movement of people and goods significantly facilitated the establishment of links of wider geographical scope, having at their disposal greater knowledge potential shared in an easier way with interested users (Mendel, 2016). Clusters are a form of organizing business and social activity of business, research, civic and public entities cooperating with one another voluntarily, on the basis of cooperation and trust, to promote, generate and implement innovation. Traditionally, cluster is identified with creating local conditions for joint business activity with the use of potential and competence of local leaders to achieve the synergy effect (Porter, 2001).

Cluster is also a cooperation platform making the knowledge transfer possible. In the recent years, the importance of clusters in creating innovations in global economy has been rising. Clusters fall into the global activities by fostering the economic development. They are supported at the EU level, as well as at the national, regional and local level. By becoming the innovation environment, they foster the local and regional innovation. The EU points to a significant role of clusters in the implementation of smart specialization strategy (European Union, 2010) at the country level, clusters are defined as modern instrument strengthening the regional and local specializations (Ministry of Regional Development, 2011).

Polish Agency for Enterprise Development, implementing activities and projects focusing on development of clusters in Poland, developed and published cluster management standards rules defining desirable management and functioning features of cluster coordinators. The objective of the publication is to improve the cluster management quality level and to make available a tool that will allow for the diagnosis of cluster management processes, identification of gaps and possibility to introduce correction. As a result of the research, five main areas were identified: organization, resources, processes, services for cluster members, cooperation with the environment. Within these areas, there are subareas (19 in total), to which specific standards were assigned (Kępka, Kacperek, 2017).

In the process area, corporate social responsibility subarea, the Corporate social responsibility standard was placed (CSR) (Kępka, Kacperek, 2017). In line with this standard, the activities of cluster within CSR mean that this standard aims to develop human resources, take into account environmental protection and build relations with the environment in its everyday practice. In this case, a specific role was assigned to coordinator that should 
implement the CSR assumptions in their activity. An additional effect stemming from the implementation of CSR rules can be image and economy benefits resulting from savings in energy and materials. The cluster can obtain a positive assessment on the implementation of this standard if it meets one of alternative indicators (Kępka, Kacperek, 2017):

1. the development strategy has information on CSR activities associated, for example, with establishing employee-friendly workplaces, development and introduction of new environmentally-friendly technologies, increase of energy efficiency, limitation of the use of natural resources, carrying out varied social activities etc.;

2. the coordinator takes up activities to promote CSR rules, for example organizes workshops or technological meetings, carries out activities aimed to establish and strengthen the awareness on CSR. The frequency, form and scale of these activities is adequate to the cluster development state, represented industry, as well as needs and possibilities of its members;

3. the coordinator supports implementation of activities, the objective of which is implementation of CSR rules (for example undertaking activities that are about familiarizing the environment with CSR rules, implementing low-carbon technologies, limiting the use of natural resources etc.). The frequency, form and scale of the activities is adequate to the cluster development state, represented industry, as well as needs and possibilities of its members.

Summarizing, corporate social responsibility is a complex concept of business model. It is based on establishing long-term relations with all participants of economic and social system, at the same time taking into account their differences and development needs. Once the interest of all participants of system organizations are taken into account, it allows for sustainable development of all of its stakeholders (Rosińska-Bukowska, 2012).

\section{Conclusion}

Positive Organizational Scholarship, as one of the newest trends of management, is dynamically developing all over the world and is becoming more and more popular. The basic POS assumption is abstaining from developing the organization by way of elimination of negative phenomena and instead is about focusing on positive aspects fostering the development and success of an organization (Moczydłowska, 2012). The currently developing positive trend in management sciences assumes that learning of an organization and its development requires extracting from people their most valuable unique features, developing their talents and strengths and transforming them into strengths of the organization. On the one hand, the implementation of POS values and premises requires specific organizational maturity, expressed by configuration of resources and skills in establishing positive and creative potential 
of the organization and, on the other hand, it requires employees that are aware of their talents, strengths and needs.

The literature analysis allowed to prove the thesis that there is a need and possibility to carry out socially responsible activity in clusters. CSR is a concept becoming more and more popular globally. One can notice the transformation of enterprise approach to the corporate social responsibility - empty declarations become strategic in their nature. There is a growing number of entities where one can observe strategic approach to CSR - enterprises try to establish their knowledge, mission and strategy based on social responsibility. The changes taking place in this area can be noticed not only by enterprises, but also by international institutions. European Commission noticing that corporate social responsibility is a crucial element of business strategy deemed it relevant to use its principles as an effective way to establish the most competitive economy in the world (Kulawczuk, Poszewiecki, 2007). It can be, therefore, assumed that companies that include the CSR rules in their visions and missions and implement strategies that are socially responsible increase the potential of their growth.

\section{References}

1. Adamczyk, J. (2009). Społeczna odpowiedzialność przedsiębiorstw. Warszawa: PWE, 53.

2. Bugdol, M. (2010). Wymiary i problemy zarzadzania organizacja oparta na zaufaniu. Kraków: Wyd. UJ, 66.

3. Cameron, K.S. (2003). Organizational Virtuousness And Performance. In: K.S. Cameron, J.E. Dutton, R.E. Quinn (Eds.), Positive Organizational Scholarship. San Francisco: Berrett-Koelher, 370.

4. Cameron, K.S., Caza, A. (2003). Contributions to the Discipline of Positive organizational Scholarship. Arizona, USA: American Behavioral Scientist, 48.

5. Cameron, K.S., Mora, C., Leutscher, T., Calarco, M. (2011). Effects of positive practices on organizational effectiveness. The Journal of Applied Behavioral Science, vol. 47, no. 3, 266.

6. Cameron, K.S. (2007). Forgiveness in Organizations. In: D.L. Nelson, C.L. Cooper, (Eds.), Positive Organizational Behavior. London: Sage, 129.

7. Czerw, A., Babiak, J. (2010). Transformacyjny styl kierowania w tworzeniu pozytywnej organizacji. Zarzadzanie Zasobami Ludzkimi, nr 6, 47-48.

8. Czekaj, J., Ziębicki, B. (2013). Positive organizational scholarhip against evolution of management theories and concepts. Organization and Management, 3, 156, 45.

9. Czop, K. (2012). Positive Organizational Scholarschip - Nowy nurt w naukach o zarządzaniu. Studia Ekonomiczne, Zeszyty Naukowe Wdziałowe Uniwersytetu Ekonomicznego w Katowicach. Katowice: Wyd. UE, 243-245. 
10. Dahlsrud, A. (2008). How corporate social responsibility is defined: an analysis of 37 definitions. Corporate Social Responsibility \& Environmental Management, nr 15(1), 4.

11. Ejdys, J., Gulc, A. (2015). Koncepcja społecznej odpowiedzialności narzędziem poprawy innowacyjności przedsiębiorstw sektora MŚP. Prace Naukowe Uniwersytetu Ekonomicznego we Wrocławiu, nr 378, 106.

12. EUROPE 2020 (2010). A strategy for smart, sustainable and inclusive growth. Commission Communication: Regional Policy contributing to smart growth, EU.

13. Fineman, S. (2006). On Being Positive: Concerns and Counterpoints. Academy of Management Review, Vol. 31, No. 2, 272-275.

14. Friedman, M. (1970). A Friedman Doctrine - The Social Responsibility of Business is to Increase its Profits. The New York Times Magazine, September, 32.

15. Freeman, R.E. (1984). Strategic Management: A Stakeholder Approach. Boston: Pitman, http://www.istheory.yorku.ca/stakeholdertheory.htm, 09.08.2019.

16. Fredrickson, B.L. (2009). Positivity: groundbreaking research reveals how to embrace the hidden strenth of positive emotions, overcome negativity, and thrive. New York, NY: Crown Publishers, 23.

17. Ghoshal, S. (2005). Bad management theories and are destroying good management practices. Academy of Management Learning \& Education, vol. 4, no. 1, 86.

18. Glińska-Neweś, A. (2011). Pozytywny potencjał organizacji jako prorozwojowa architektura zasobów przedsiębiorstwa. In: M.J. Stankiewicz (ed.), Pozytywny Potencjat Organizacji. Wstęp do użytecznej teorii zarzadzania. Toruń: Dom Organizatora, 45.

19. ISO 26000 (2011). Międzynarodowa Organizacja Normalizacyjna, Norma ISO 26000.

20. Jonker, J., Rudnicka, A., Reichel, J. (2011). Nowe horyzonty. Przewodnik po społecznej odpowiedzialności i rozwoju zrównoważonym. Łódź: Centrum Strategii i Rozwoju Impact, 19.

21. Kalinowska-Andrian, K. (2006). Positive Organizational Scholarship - nowy trend w nauce zarządzania. Zaproszenie do świata pozytywów. E-mentor, $n r$ 1(13), http://www.e-mentor. edu.pl/, 14.08.2019.

22. Kępka, B., Kacperek, D. (2017). Wdrażanie standardów zarządzania klastrem. Poradnik dla koordynatorów. Warszawa: Wyd. PARP, 3-6, 37-38,

23. Kulawczuk, P., Poszewiecki, A. (2007). Wpływ społecznej odpowiedzialności biznesu $i$ etyki biznesu na zarządzanie przedsiębiorstwami. Warszawa: IBnDiPP, 164. http://www.iped.pl/publikacje/ podrecznik_zfp_2007.pdf, 14.08.2019.

24. Maciąg, J. (2015). Zastosowanie koncepcji społecznej odpowiedzialności w tworzeniu sieciowego produktu turystycznego w regionie. Prace Naukowe Uniwersytetu Ekonomicznego we Wrocławiu, nr 378.

25. Margolis, J.D. and Walsh, J.P. (2002). Misery loves companies.: Whither social initiatives by business? University of Michigan Business School. 
26. Mendel, I. (2016). Klastry społecznie odpowiedzialne. http://odpowiedzialnybiznes.pl, 14.08.2019.

27. Moczydłowska, J. (2012). Koncepcja Positive Organizational Scholarship. In: Współczesne przedsiębiorstwo. A. Sopińska (ed.). Teoria i praktyka. Warszawa: Oficyna Wydawnicza SGH, 53-54.

28. Porter, M.E. (2001). Porter o konkurencji. Warszawa: PWE, 246.

29. Rosińska-Bukowska, M. (2012). Społeczna odpowiedzialność biznesu w procesie kreacji wartości dodanej przedsiębiorstwa. In: M. Jabłoński, K. Zamasz (eds.), Kreacja wartości przedsiębiorstw. Nowe trendy i kierunki rozwoju. Prace Naukowe Wyższej Szkoły Biznesu w Dąbrowie Górniczej. Dąbrowa Górnicza, 332-334.

30. Sonenshein, S. (2005). Positive Organizational Scholarship. In: P.H. Werhane \& R.E. Freeman (eds.), The Blackwell Encyclopedia of Management, Vol. II. Business Ethics, Oxford: Blackwell Publishing, 410-414.

31. Strategia rozwoju kraju 2020 (2011). Projekt Ministerstwa Rozwoju Regionalnego, 65.

32. Wang, C.S., \& Thompson, L.L. (2006). The negative and positive psychology of leadership and group research. The Social Psychology of the Workplace. Advances in Group Processes, Vol. 23. New York: Elsevier, 31-61.

33. Whetten, D.A., Rands, G., and Godfrey, P. (2001). What are the responsibilities of business to society? In: A. Pettigrew, H. Thomas, H.R. Whittington, (Eds.), Handbook of Strategy and Management. London, 373.

34. Wright, T., Cropanzano, R. (2004). The role of psychological well-being in job performance: a fresh look at an age-old quest. Organizational Dynamics, vol. 33, 4, 338.

35. Valentine, S., Godkin, L., Fleischman, G.M., Kidwell, R. (2011). Corporate ethical values, group creativity, job satisfaction and turnover intention: the impact of work context on work response. Journal of Business Ethics, vol. 98, no. 3, 355.

36. Żemigała, M. (2007). Społeczna odpowiedzialność przedsiębiorstwa. Wolters Kluwer, Warszawa, 32. 